\title{
Growth of Nano- and Microstructured Indium Nitride Crystals by the Reaction of Indium Oxide with Ammonia
}

\author{
Woo-Sik Jung, ${ }^{*}$ Choon Sup Ra, ${ }^{\dagger}$ and Bong-Ki Min \\ School of Chemical Engineering and Technology, College of Engineering, Yeungnam University, Gyongsan 712-749, Korea \\ *E-mail:wsjung@yu.ac.kr \\ ${ }^{\dagger}$ Department of Chemistry and Institute of Natural Science, Yeungnam University, Gyongsan 712-749, Korea \\ ${ }^{\sharp}$ Instrumental Analysis Center, Yeungnam University, Gyongsan 712-749, Korea \\ Received April 15, 2005
}

\begin{abstract}
Nano- and microstructured indium nitride crystals were synthesized by the reaction of indium oxide $\left(\operatorname{In}_{2} \mathrm{O}_{3}\right)$ powder and its pellet with ammonia in the temperature range $580-700{ }^{\circ} \mathrm{C}$. The degree of nitridation of $\operatorname{In}_{2} \mathrm{O}_{3}$ to InN was very sensitive to the nitridation temperature. The formation of zero- to three-dimensional structured InN crystals demonstrated that $\operatorname{In}_{2} \mathrm{O}_{3}$ is nitridated to $\mathrm{InN}$ via two dominant parallel routes ( $\operatorname{solid}\left(\operatorname{In}_{2} \mathrm{O}_{3}\right)$-to-solid $(\mathrm{InN})$ and gas $\left(\operatorname{In}_{2} \mathrm{O}\right)$-to-solid $\left.(\mathrm{InN})\right)$. The growth of $\mathrm{InN}$ crystals with such various morphologies was explained by the vapor-solid (VS) mechanism where the degree of supersaturation of In vapor determines the growth morphology and the vapor was mainly by the reaction of $\operatorname{In}_{2} \mathrm{O}$ with ammonia and partially by sublimation of solid InN. The pellet method was proven to be useful to obtain homogeneous InN nanowires.
\end{abstract}

Key Words : Indium nitride, Indium oxide, Nanowires, Growth mechanism, VS mechanism

\section{Introduction}

Indium nitride $(\mathrm{InN})$, one of Group 13 nitrides, with a direct bandgap of $1.9 \mathrm{eV}$ is a promising material for optoelectronic devices, low-cost solar cells with high efficiency, optical coatings and various sensors. ${ }^{1}$ However, it remains one of the least studied Group 13 nitrides because of the inherent difficulty of its preparation in stoichiometric form. The equilibrium vapor pressure of $\mathrm{N}_{2}$ over $\mathrm{InN}$ is much higher than that over other Group 13 nitrides such as $\mathrm{GaN}$ and $\mathrm{AIN}$, and the In-N bond is the weakest of these nitrides. ${ }^{2}$ InN films have been prepared by various methods such as reactive magnetron sputtering, metalorganic chemical vapor deposition (MOCVD) and molecular-beam epitaxy (MBE). ${ }^{3}$ However, up to now there is little information concerning synthetic methods of InN powders. ${ }^{4-6}$ And onedimensional structured $\mathrm{InN}$ has been reported in recent years. ${ }^{7-13}$

In this report, nano- and microstructured $\mathrm{InN}$ crystals were synthesized by the reaction of indium oxide $\left(\operatorname{In}_{2} \mathrm{O}_{3}\right)$ powder and its pellet with ammonia. The pellet contains a mixture of $\mathrm{In}_{2} \mathrm{O}_{3}$ and $\mathrm{Al}_{2} \mathrm{O}_{3}$ powders. It will be shown that the pellet method is useful for preparation of $\mathrm{InN}$ nanowires. The plausible reaction mechanism on conversion of $\operatorname{In}_{2} \mathrm{O}_{3}$ to $\mathrm{InN}$ and growth mechanism of InN crystals will be suggested on the basis of various morphologies of InN crystals formed.

\section{Experimental Section}

The precursor material, indium oxide $\left(\mathrm{In}_{2} \mathrm{O}_{3}\right)$ in cubic phase (Kojundo Chemical Lab Co., 99.99\%), was used without further purification. The $\operatorname{In}_{2} \mathrm{O}_{3}$ powder in an alumina crucible was set in an alumina tube with an inner diameter of $33 \mathrm{~mm}$ and heated at a rate of $5{ }^{\circ} \mathrm{C} \mathrm{min}^{-1}$ to the reaction temperature $\left(580-700{ }^{\circ} \mathrm{C}\right)$ under an ammonia (Showadenko

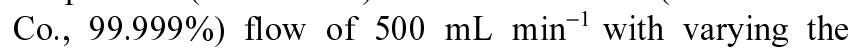
duration time. Care was taken to keep the crucible closest to the thermocouple of the furnace to ensure that the temperature of the furnace matches with that of the crucible. The sample nitridated was taken from the furnace after it was cooled to the room temperature under a flow of ammonia. InN nanowires were obtained by calcining pellets containing a homogeneous mixture of $\mathrm{In}_{2} \mathrm{O}_{3}$ and $\mathrm{Al}_{2} \mathrm{O}_{3}$ (mole ratio $=0.1: 1)$ powders. The pellets were prepared in disc form of $1 \mathrm{~cm}$ radius and $0.5 \mathrm{~mm}$ thickness by using a die and a hydraulic press. A pellet was put on another pellet, followed by being nitridated in flowing ammonia.

The conversion of $\mathrm{In}_{2} \mathrm{O}_{3}$ to $\mathrm{InN}$ was monitored by the weight loss and XRD (Rigaku DMX-2500 diffractometer with $\mathrm{Cu}-\mathrm{K} \alpha$ radiation operating at $40 \mathrm{kV}$ and $100 \mathrm{~mA}$ ). The morphology of InN products was investigated by scanning electron microscopy (SEM, Hitachi S-4100), transmission electron microscopy (TEM, Philips CM 200 STEM at 200 $\mathrm{kV}$ ), and selected-area electron diffraction (SAED).

\section{Results and Discussion}

Nitridation of $\mathrm{In}_{2} \mathrm{O}_{3}$ Powder by Ammonolysis. The precursor material, $\mathrm{In}_{2} \mathrm{O}_{3}$ in cubic phase, was nitridated to InN by ammonolysis at different reaction temperatures varying the duration time. Figure 1 shows XRD patterns of samples synthesized at different temperatures. The degree of nitridation of $\mathrm{In}_{2} \mathrm{O}_{3}$ to $\mathrm{InN}$ was very sensitive to the nitridation temperature. Figure 1(a) shows that the sample nitridated at $580{ }^{\circ} \mathrm{C}$ for $8 \mathrm{~h}$ has diffraction peaks (JCPDS Card No. 2-1450) assigned to InN together with those assigned to unreacted $\operatorname{In}_{2} \mathrm{O}_{3}$. The intensities of the former peaks increased with the nitridation temperature. As shown 


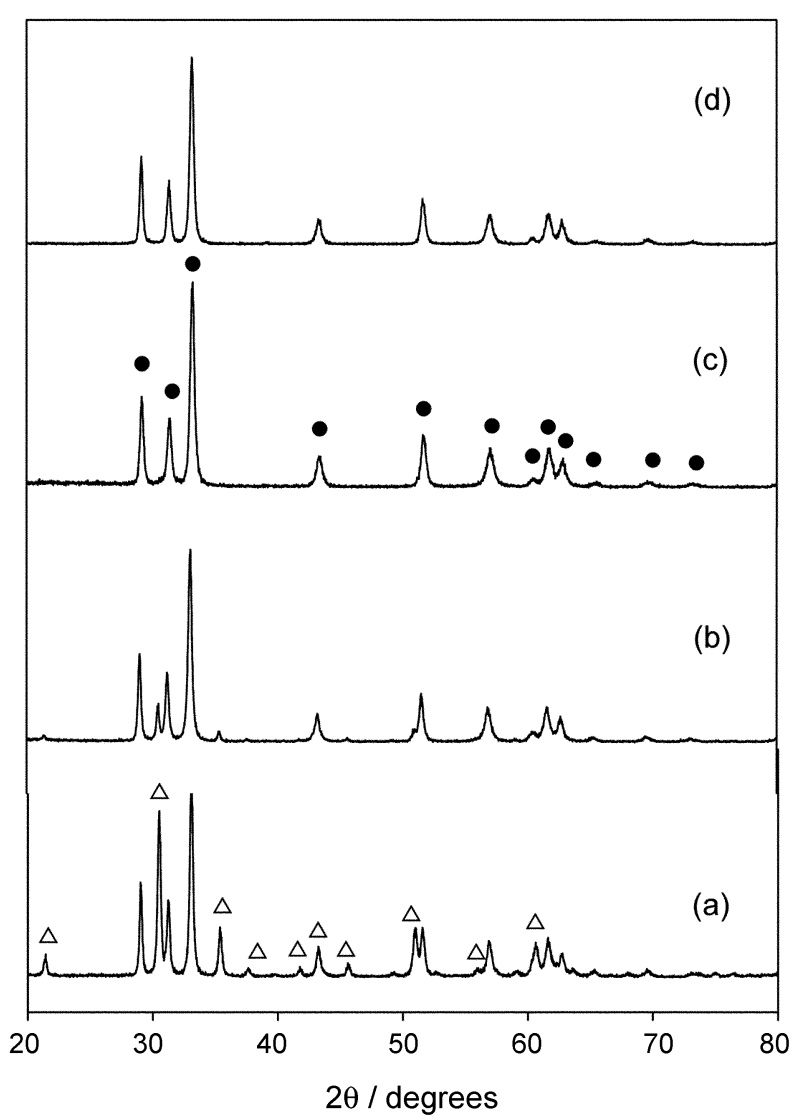

Figure 1. XRD patterns of powders obtained by nitridation of $\mathrm{In}_{2} \mathrm{O}_{3}$ in flowing ammonia at (a) $580{ }^{\circ} \mathrm{C}$ for $8 \mathrm{~h}$, (b) $600{ }^{\circ} \mathrm{C}$ for $8 \mathrm{~h}$, (c) $600{ }^{\circ} \mathrm{C}$ for $12 \mathrm{~h}$, and (d) $620^{\circ} \mathrm{C}$ for $8 \mathrm{~h}$. ( • ) InN, ( $\triangle$ ) $\operatorname{In}_{2} \mathrm{O}_{3}$.

in Figure 1(c), the nitridation of $\operatorname{In}_{2} \mathrm{O}_{3}$ to $\mathrm{InN}$ was complete at $600{ }^{\circ} \mathrm{C}$ for $12 \mathrm{~h}$. At temperatures above $600{ }^{\circ} \mathrm{C}$ the shorter duration time was required for the complete nitridation, as shown in Figure 1(d). The nitridation above $620^{\circ} \mathrm{C}$ for $20 \mathrm{~h}$ caused InN products to swell like a cotton candy and indium droplets to be observed at the bottom of the alumina crucible because of decomposition of $\mathrm{InN}$ into indium metal and $\mathrm{N}_{2}$ gas.

The conversion of $\operatorname{In}_{2} \mathrm{O}_{3}$ to $\mathrm{InN}$ by ammonolysis was accompanied by weight loss (which is defined by $100(1-$ weight of the product/weight of the precursor used)). The weight loss of $7.2 \%$ will be obtained theoretically if there is no loss of In species from the reaction system during the nitridation reaction and $\operatorname{In}_{2} \mathrm{O}_{3}$ is completely converted to InN. If the reaction temperature was higher than $620^{\circ} \mathrm{C}$ and the duration time was longer than $8 \mathrm{~h}$, the single phase of InN was detected by XRD but the weight loss was higher than $7.2 \%$. The latter fact is mainly ascribed to decomposition of InN into metallic In and $\mathrm{N}_{2}$ and partially ascribed to sublimation of $\mathrm{InN}$. As the reaction temperature became higher than $640{ }^{\circ} \mathrm{C}$, the yield of $\mathrm{InN}$ powder abruptly decreased along with increase in the amount of In metal. For example, the yield of an $\mathrm{InN}$ product was around $1 \%$ for the nitridation at $700{ }^{\circ} \mathrm{C}$ for $4 \mathrm{~h}$. As a consequence, the optimum temperature range is very narrow $\left(600\right.$ to $620{ }^{\circ} \mathrm{C}$ ) for preparation of $\mathrm{InN}$ products in good yield.
The SEM micrographs of as-synthesized InN products demonstrated that their morphology is strongly dependent on the nitridation temperature. Figure 2(a) shows the morphology of InN products obtained at $600{ }^{\circ} \mathrm{C}$ for $12 \mathrm{~h}$, which were still particles. Their size was much lager than that of the precursor $\left(\operatorname{In}_{2} \mathrm{O}_{3}\right)$ powders. As shown in Figure 2(b), InN products synthesized at $610{ }^{\circ} \mathrm{C}$ for $20 \mathrm{~h}$ consisted of short nanorods with a conical tip. Figure 2(c) shows the morphology of InN powders obtained at $630{ }^{\circ} \mathrm{C}$ for $20 \mathrm{~h}$, most of them being mainly nanorods with a diameter of $c a$. $130 \mathrm{~nm}$. The longer duration time $(\sim 40 \mathrm{~h})$ at $630{ }^{\circ} \mathrm{C}$ led to the formation of microplates as well as nanorods. InN products prepared in the temperature range $630-680{ }^{\circ} \mathrm{C}$ were a mixture of nanorods and microplates. InN products formed at $700{ }^{\circ} \mathrm{C}$ for $4 \mathrm{~h}$ involved some hollow microtubes and lobster shell-like microstructures besides nanorods and microplates, as shown in Figure 2(d).

Figure 3(a) shows a TEM image of the InN nanorod obtained at $620^{\circ} \mathrm{C}$ for $20 \mathrm{~h}$. The long axis of the nanorod is normal to the (0001) plane, with the preferred direction being [001]. The selected area electron diffraction (SAED) pattern (Figure 3(b)) indicates high crystallinity of the nanorods.

The dramatic change in morphology with temperature indicates the involvement of any gaseous In species in conversion of $\mathrm{In}_{2} \mathrm{O}_{3}$ to $\mathrm{InN}$. The predominant gaseous species is most likely to be $\operatorname{In}_{2} \mathrm{O}$, which is formed mainly by the reaction between $\operatorname{In}_{2} \mathrm{O}_{3}$ and $\mathrm{In}$ and partially by the decomposition of $\operatorname{In}_{2} \mathrm{O}_{3} .{ }^{14}$ Therefore, we suggest that there would be two dominant parallel routes in conversion of $\mathrm{In}_{2} \mathrm{O}_{3}$ to $\mathrm{InN}$ by ammonolysis, i.e., solid $\left(\mathrm{In}_{2} \mathrm{O}_{3}\right)$-to-solid $(\mathrm{InN})$ and gas $\left(\operatorname{In}_{2} \mathrm{O}\right)$-to-solid $(\mathrm{InN})$ conversion routes. At the initial stage $\mathrm{InN}$ is formed by the solid-to-solid conversion route and then decomposes into metallic In and nitrogen. The metallic In reacts with $\operatorname{In}_{2} \mathrm{O}_{3}$, leading to the formation of gaseous $\mathrm{In}_{2} \mathrm{O}$. The reaction of the resulting $\mathrm{In}_{2} \mathrm{O}$ with ammonia, which is expected to be fast because of a gas-gas reaction, yields InN. As a result, the main conversion routes from $\operatorname{In}_{2} \mathrm{O}_{3}$ to $\mathrm{InN}$ are summarized as follows:

\section{Route I:}

$$
\mathrm{In}_{2} \mathrm{O}_{3}(\mathrm{~s})+2 \mathrm{NH}_{3}(\mathrm{~g}) \rightarrow 2 \mathrm{InN}(\mathrm{g}, \mathrm{s})+3 \mathrm{H}_{2} \mathrm{O}(\mathrm{g})
$$

Route II:

$$
\begin{aligned}
& 2 \mathrm{InN}(\mathrm{g}, \mathrm{s}) \rightarrow 2 \operatorname{In}(\mathrm{l})+\mathrm{N}_{2}(\mathrm{~g}) \\
& \mathrm{In}_{2} \mathrm{O}_{3}(\mathrm{~s})+4 \operatorname{In}(\mathrm{l}) \rightarrow 3 \operatorname{In}_{2} \mathrm{O}(\mathrm{g}) \\
& \mathrm{In}_{2} \mathrm{O}(\mathrm{g})+2 \mathrm{NH}_{3}(\mathrm{~g}) \rightarrow 2 \operatorname{InN}(\mathrm{g}, \mathrm{s})+\mathrm{H}_{2} \mathrm{O}(\mathrm{g})+2 \mathrm{H}_{2}(\mathrm{~g})
\end{aligned}
$$

At relatively low temperatures (below $600{ }^{\circ} \mathrm{C}$ ) Route I prevails over Route II. InN products prepared by Route I take a form of particle, as shown in Figure 2(a). With increasing temperature Route II becomes more distinct, leading to the formation of $\mathrm{InN}$ products with various morphologies, as shown in Figure 2(b)-(d). Some investigators synthesized $\mathrm{InN}$ nanowires though a combination of (3) and (4) reactions, i.e., by the reaction of a mixture of 

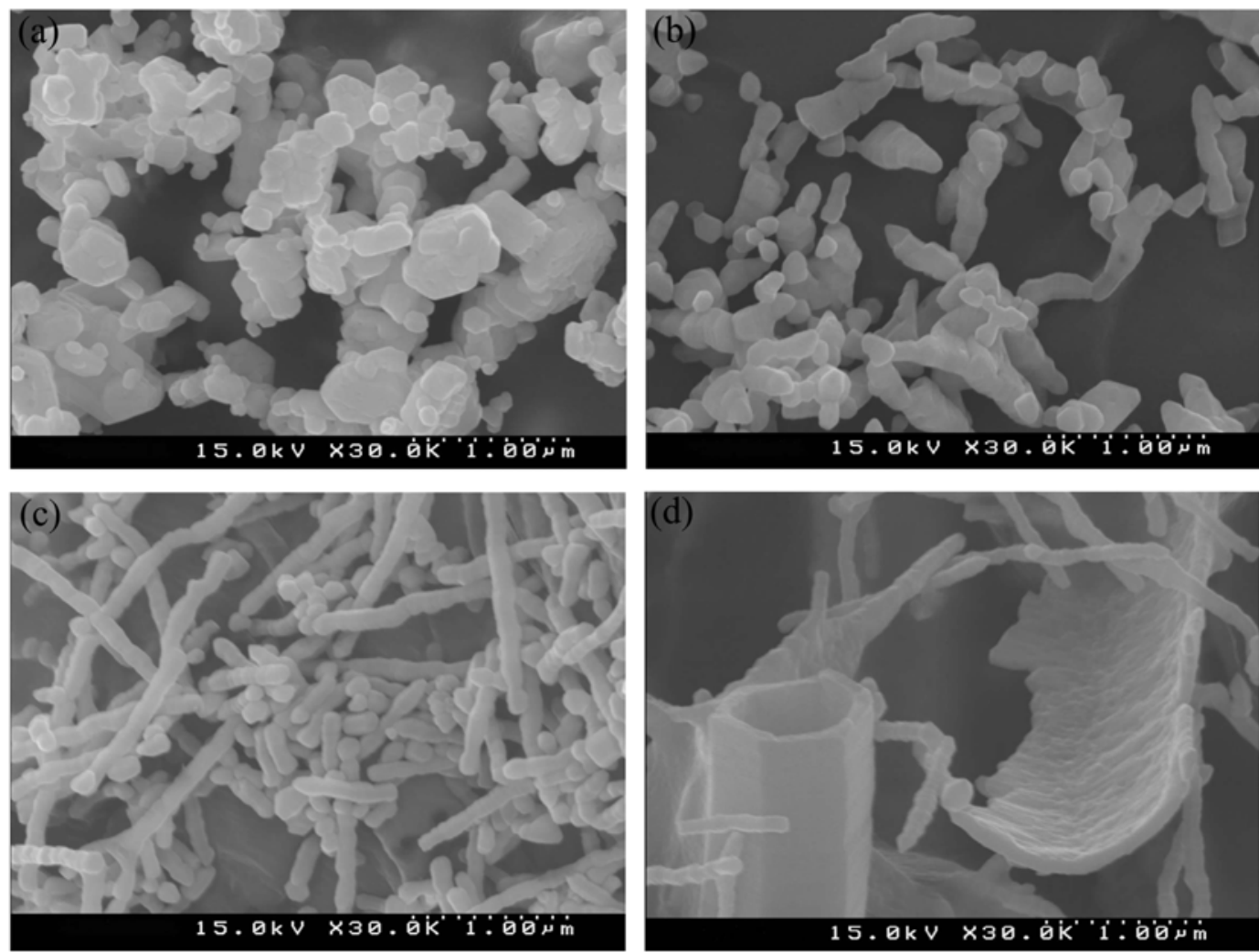

Figure 2. SEM micrographs of $\mathrm{InN}$ powders obtained by nitridation of $\operatorname{In}_{2} \mathrm{O}_{3}$ in flowing ammonia at (a) $600{ }^{\circ} \mathrm{C}$ for $12 \mathrm{~h}$, (b) $610{ }^{\circ} \mathrm{C}$ for $20 \mathrm{~h}$, (c) $630{ }^{\circ} \mathrm{C}$ for $20 \mathrm{~h}$, and (d) $700{ }^{\circ} \mathrm{C}$ for $4 \mathrm{~h}$.

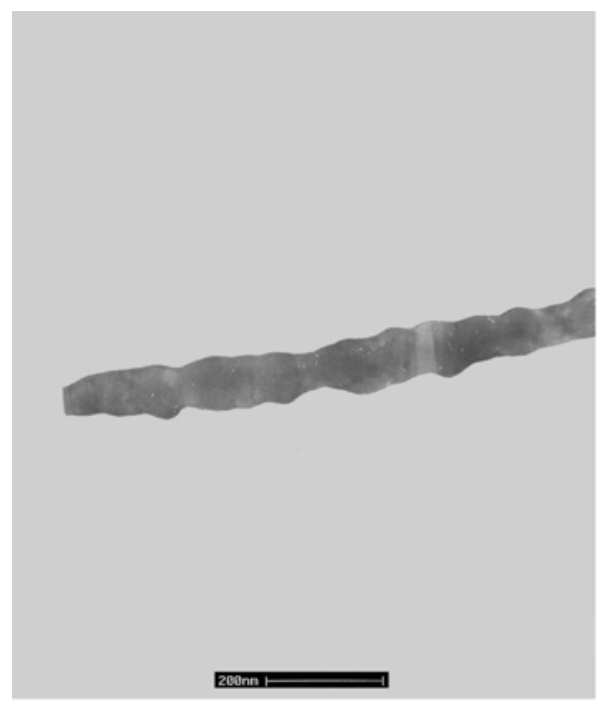

(a)

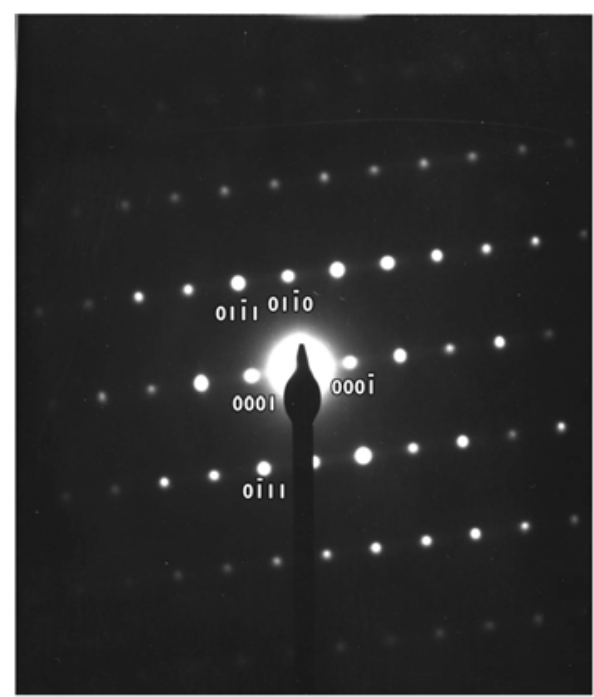

(b)

Figure 3. High-magnification TEM image of the $\mathrm{InN}$ nanowire obtained by nitridation of $\mathrm{In}_{2} \mathrm{O}_{3}$ in flowing ammonia at $630{ }^{\circ} \mathrm{C}$ for $20 \mathrm{~h}$ : (a) bright-field image, the direction of the axis is [001]. Bar $=200 \mathrm{~nm}$; (b) SAED pattern, the zone axis is [2 110$]$.

$\mathrm{In}_{2} \mathrm{O}_{3}$ and In with ammonia. ${ }^{8,11}$ The reaction mechanism proposed in this work is quite different from that suggested by Gao et $a l^{5}$ where metallic In formed by reduction of $\mathrm{In}_{2} \mathrm{O}_{3}$ by $\mathrm{H}_{2}$ reacts with $\mathrm{N}_{2}$, resulting in formation of $\mathrm{InN}$. The $\mathrm{H}_{2}$ and $\mathrm{N}_{2}$ are derived from decomposition of $\mathrm{NH}_{3}$.

The growth of In crystals with various morphologies from vapor phase is explained by the vapor-solid (VS) growth mechanism where the degree of supersaturation determines the prevailing growth morphology. ${ }^{15}$ A low supersaturation is required for growth of one-dimensional (1D) structures whereas a medium supersaturation supports bulk crystal growth; an intermediate supersaturation is evidenced by the growth of two-dimensional (2D) platelets. None of the InN nanorods formed from $\mathrm{In}_{2} \mathrm{O}_{3}$ powders in this work showed 
characteristic vapor-liquid-solid (VLS) droplets on their tips, as shown in Figures 2(b), 2(c), and 3(a); although this observation does not exclude the VLS mechanism, it does suggest growth through the VS mechanism. Kato and Tamari suggested that at the initial stage, the formation of one-dimensional structures proceeded by the VLS mechanism, followed by the removal of droplets by evaporation and continued growth by the VS mechanism. ${ }^{16}$ It is possible that their mechanism was responsible for nanorod growth in the present study. In this case, the molten indium would serve as a catalyst.

Two-dimensional (2D) microstructures such as microplates and lobster shell-like microstructures were also observed (Figure 2(d)), indicating that there were some local regions under an intermediate supersaturation. Hollow microtubes are likely to be formed through the twodimensional microstructure under an intermediate supersaturation (see below). Some microtubes had holes at their walls because of lack in feed of $\mathrm{InN}$ vapor. The morphology became more diverse with increasing the reaction temperature because the overall degree of supersaturation would increase with the temperature. Thus, the local degree of supersaturation within powders may have played a crucial role on the morphology distribution of the formed $\mathrm{InN}$ products.

Nitridation of $\operatorname{In}_{2} \mathrm{O}_{3}$ Pellets by Ammonolysis. As seen
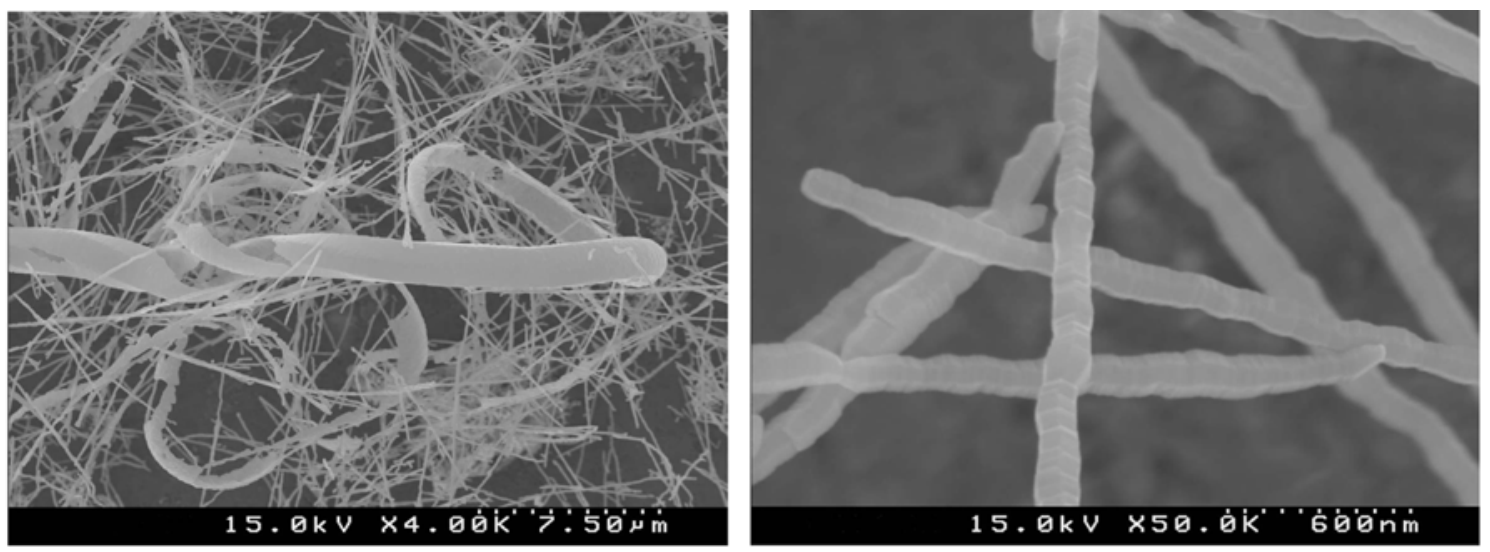

Figure 4. SEM micrographs of the $\mathrm{InN}$ product obtained by nitridation of $\operatorname{In}_{2} \mathrm{O}_{3}$ pellets at $620{ }^{\circ} \mathrm{C}$ for $40 \mathrm{~h}$ in flowing ammonia.
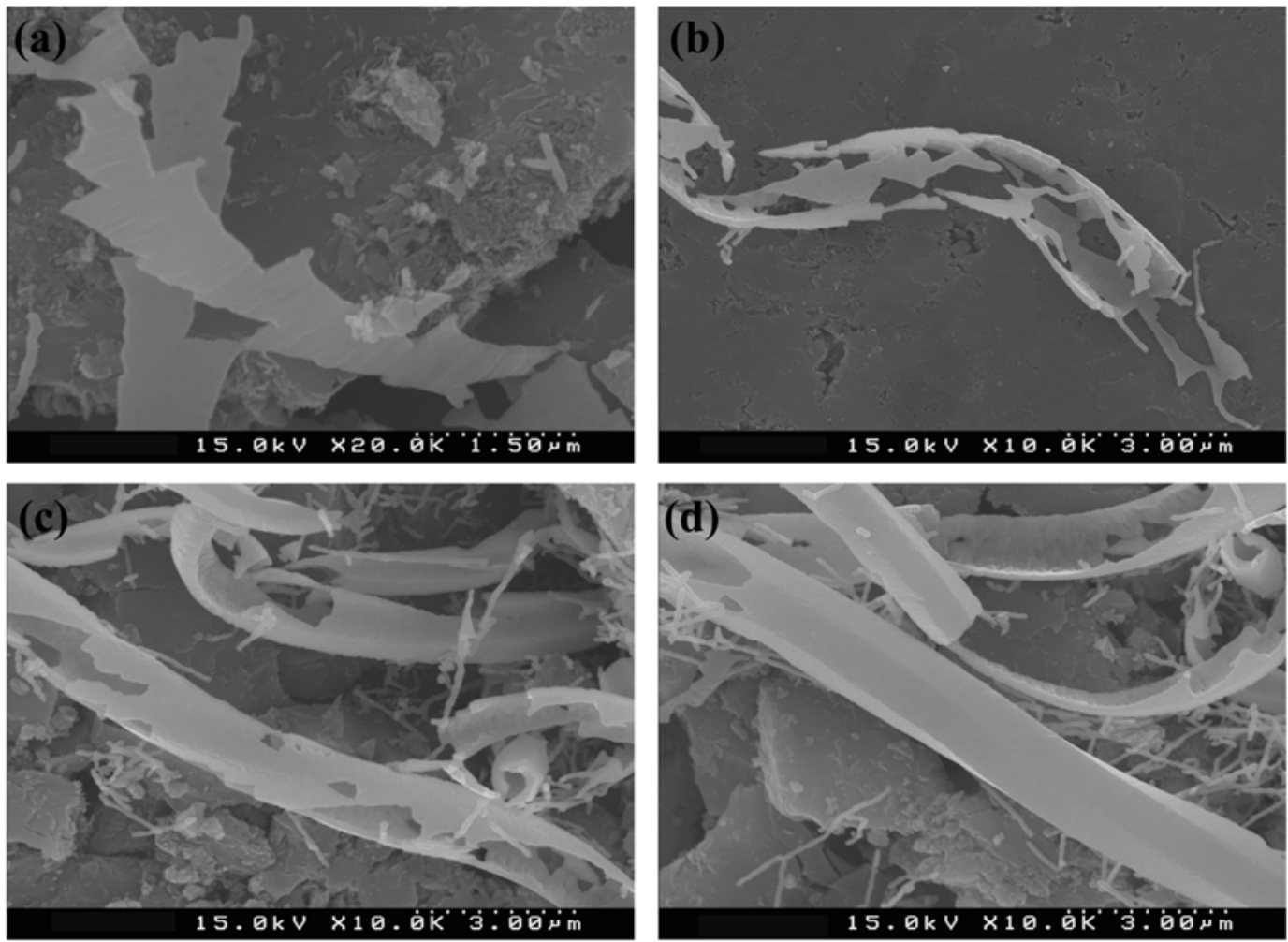

Figure 5. SEM micrographs showing the formation process $(\mathrm{a} \rightarrow \mathrm{b} \rightarrow \mathrm{c} \rightarrow \mathrm{d})$ of a hollow microtube. The InN sample was obtained by nitridation of $\mathrm{In}_{2} \mathrm{O}_{3}$ pellets at $700{ }^{\circ} \mathrm{C}$ for $5 \mathrm{~h}$ in flowing ammonia. 
from above-mentioned results, the 1D structure of $\mathrm{InN}$ obtained from $\operatorname{In}_{2} \mathrm{O}_{3}$ powders was not a nanowire but a nanorod. Nanowires can be easily synthesized by a pellet method. In a previous report ${ }^{17}$ we synthesized GaN nanowires by the pellet method, in which GaN vaporizes and a confined space formed by pressing a matrix material therby becomes supersaturated with $\mathrm{GaN}$ vapor. To obtain $\mathrm{InN}$ nanowires $\mathrm{In}_{2} \mathrm{O}_{3}$ pellets were prepared by pressing a homogeneous mixture of $\mathrm{In}_{2} \mathrm{O}_{3}$ and $\mathrm{Al}_{2} \mathrm{O}_{3}$ powders, leading to confinement of $\operatorname{In}_{2} \mathrm{O}_{3}$ in an $\mathrm{Al}_{2} \mathrm{O}_{3}$ matrix. A pellet was put on another pellet and then nitridated by ammonia. InN products including many nanowires were found both within the interspace between two pellets and on two surfaces confronting two pellets each other, whereas no InN products were found on the other two surfaces of pellets.

Figure 4 shows SEM micrographs of the $\mathrm{InN}$ product which was obtained at $620{ }^{\circ} \mathrm{C}$ for $40 \mathrm{~h}$. The distribution of their morphologies was quite different from that of $\mathrm{InN}$ products obtained by using $\operatorname{In}_{2} \mathrm{O}_{3}$ powders under the same condition. The $\mathrm{InN}$ product consisted of nanowires with a diameter of $\sim 100 \mathrm{~nm}$, lobster shell-like microstructures and imperfect hollow microtubes. The InN product obtained at $700{ }^{\circ} \mathrm{C}$ for $5 \mathrm{~h}$ involved nanowires, flat microplates, lobster shell-like microstructures, and hollow microtubes. Figure 5 demonstrates the formation process of a hollow microtube. The microtube may be a two-dimensional microstructure at its initial stage, as shown in Figure 5(a). By continuous feeding of InN vapor the microstructure transforms into a three-dimensional microstructure (Figure 5(d)) through those of Figures 5(b) and (c).

The growth of nano- and microstructured InN crystals from $\mathrm{In}_{2} \mathrm{O}_{3}$ pellets is also explained by the VS mechanism as follows. $\mathrm{In}_{2} \mathrm{O}_{3}$ in a confined space below the surfaces of pellets is nitridated to $\mathrm{InN}$ by ammonia and then $\operatorname{In}_{2} \mathrm{O}$ vapor is formed by a combination of (2) and (3) reactions of Route II. The $\mathrm{In}_{2} \mathrm{O}$ vapor comes out into the interspace and then convert to $\mathrm{InN}$ by the reaction (4). The interspace is supersatutared with InN vapor, followed by nucleation and growth of InN crystals. The fact that most of InN crystals were nanowires indicates that the degree of supersaturation within the interspace is controlled at a low level. The distribution of InN nano- and microstructures was not homogeneous within the interface but different from region to region, indicating that the degree of supersaturation was not the same throughout the interspace. The local difference in the morphology strongly suggests that InN nano- and microstructures grow independently except the transformation of two- into three-dimensional microstructures. This is contrary to the growth mechanism proposed by Schwenzer et al. ${ }^{10}$ where InN nanoparticles transform into nanowires and then into hollow microtubes.

The reason why no InN products were found on the upside surface of the upper pellet and the downside surface of the lower pellet is that $\operatorname{In}_{2} \mathrm{O}$ vapor formed in the confined spaces easily scatters and does not supersaturate enough to nucleate because the spaces are open outward.

\section{Conclusions}

Nano- and microstructured InN crystals with a variety of morphologies were synthesized by the reaction of $\operatorname{In}_{2} \mathrm{O}_{3}$ powder and its pellet with ammonia at different temperatures. The reaction temperature should be controlled between 600 and $620{ }^{\circ} \mathrm{C}$ in order to obtain $\mathrm{InN}$ product from $\mathrm{In}_{2} \mathrm{O}_{3}$ powder in good yield. The growth of nano- and microstructured InN crystals was explained by the VS growth mechanism where the main morphology-determining factor is the degree of supersaturation. The In vapor in the VS mechanism is believed to be formed mainly by the reaction of gaseous $\operatorname{In}_{2} \mathrm{O}$ with ammonia and partially by sublimation of solid InN. The local difference in the morphology strongly suggests that InN nano- and microstuctures grow independently except the transformation of two- into three-dimensional microstructures. The pellet method was proven to be useful to obtain homogeneous InN nanowires.

Acknowledgement. This work was supported by Yeungnam University Research Grant (106117). The XRD patterns, SEM, and TEM were recorded at the Yeungnam University Instrumental Analysis Center.

\section{References}

1. Strite, S.; Morkoç, H. J. Vac. Sci. Technol. 1992, B10, 1237.

2. Krukowski, S.; Witek, A.; Adamczyk, J.; Jun, J.; Bockowski, M.; Grzegory, I.; Lucznik, B.; Nowak, G.; Wróbleski, M.; Presz, A.; Gierlotka, S.; Stelmach, S.; Palosz, B.; Porowski, S.; Zinn, P. J. Phys. Chem. Solids 1998, 59, 289.

3. Bhuiyan, A. B.; Hashimoto, A.; Yamamoto, A. J. Appl. Phys. 2003, 94, 2779.

4. Bai, Y.-J.; Liu, Z.-G.; Xu, X.-G.; Cui, D.-L.; Hao, X.-P.; Feng, X.; Wang, Q.-L. J. Crystal Growth 2002, 241, 189.

5. Gao, L.; Zhang, Q.; Li, J. J. Mater. Chem. 2003, 13, 154.

6. Xiao, J.; Xie, Y.; Luo, W. Inorg. Chem. 2003, 42, 107.

7. Dingman, S. D.; Rath, N. P.; Markowitz, P. D.; Gibbons, P. C.; Buhro, W. E. Angew. Chem. Int. Ed. 2000, 39, 1470.

8. Zhang, J.; Zhang, L.; Peng, X.; Wang, X. J. Mater. Chem. 2002, $12,802$.

9. Parala, H.; Devi, A.; Hipler, F.; Maile, E.; Birkner, A.; Becker, H. W.; Fisher, R. A. J. Crystal Growth 2001, 231, 68.

10. Schwenzer, B.; Loeffler, L.; Seshadri, R.; Keller, S.; Lange, F. F.; DenBaars, S. P.; Mishra, U. K. J. Mater. Chem. 2004, 14, 637.

11. Tang, T.; Han, S.; Jin, W.; Liu, X.; Li, C.; Zhang, D.; Zhou, C.; Chen, B.; Han, J.; Meyyapan, M. J. Mater. Res. 2004, 19, 423.

12. Yin, L.-W.; Bando, Y.; Golberg, D.; Li, M.-S. Adv. Mater. 2004, $16,1833$.

13. (a) Liang, C. H.; Chen, L. C.; Hwang, J. S.; Chen, K. H.; Hung, Y. T.; Chen, Y. F. Appl. Phys. Lett. 2002, 81, 22. (b) Lan, Z. H.; Wang, W. M.; Sun, C. L.; Shi, S. C.; Hsu, C. W.; Chen, T. T.; Chen, K. H.; Chen, C. C.; Chen, Y. F.; Chen, L. C. J. Crystal Growth 2004, 269, 87.

14. Hinchcliffe, A. J.; Ogden, J. S. J. Phys. Chem. 1973, 77, 1973.

15. Campbell, W. B. Whisker Technology; Wiley-Interscience: New York, 1970; Chap. 2.

16. Kato, A.; Tamari, N. J. Crystal Growth 1979, 49, 199.

17. Jung, W.-S. Bull. Korean Chem. Soc. 2004, 25, 51. 